\title{
岩盤地下水の水質・同位体組成調查*（1）
}

\author{
本島 勲**
}

\section{Investigations on Water Quality and Isotopic Composition of Ground Water in Bedrock ( I )}

Isao Motozima

The Water Quality and isotopic composition on $T,{ }^{222} \mathrm{Rn}, \mathrm{D}$ and ${ }^{18} \mathrm{O}$ of ground water discharge in the adit for power station were investigated.

Main obtained results are summarized as follows:

1 ) Investigation on the quality of ground water shows that the ground water is intermixed by comparable amount of surface water.

2 ) Investigation on the isotopic composition of ground water also shows the same result as inferred from water quality.

3 ) It is expectated that the characteristics of origin and intermixed surface water are cleared by detailed investigations on $\mathrm{T},{ }^{222} \mathrm{Rn}, \mathrm{D}$ and ${ }^{18} \mathrm{O}$ isotopic composition of ground water discharge.

\section{I はじめに}

地下水の挙動は気象、地形、地質要素などと一体 化したもので、特に岩盤内の地下水は地質要素に大 きく支配される。岩盤内の地下水問題を考える場合、 こうした要素を考虑し流れの系全体としてその挙動 をとらえることが重要である。

しかるに、従来、岩盤内の地下水調查に利用さ れてきたルジオン試験、地下水圧試験、またはトレー

*日本地下水学会昭和 57 年度秋季講演会および昭和 58 年 度春季講演会に概要発表

**電力中央研究所 Central Research Institute of Electric Power Industry
サー試験などでは、地下水の流れの系内のほんの一 部を点または線で知るに過ぎない。さらに、地下水 の流れをダルィ流として説明しているが、実际の 岩盤内の地下水は岩盤の節理などに依存する透水度 の相対的に大きな個所を流動し、特に岩盤の透水度 が比較的小さい場合には近傍に高い水压を有する地 下水が存在していてもポテンシャルをもった地下水 を確認できない場合があるなど、タルシィ流のみで は説明が困難な場合が多い(Motozima, et al. . 1981)。このように自然という複雑さの中で、岩艋 内の地下水の場合、従来の調査法のみでは地下水の 賦存状態とその挙動を流れの系全体として把握する には不充分といわざるを得ない。深部岩盤内の地下 
水については一層困難であろう。

一方、地下水の流れは一般に他の循環水に比へ極 めておそく、地下での岩石や土壌との接触時間が非 常に長い。このため、地下水の化学組成は地下水の 存在している地質と密接な関係にあり、地下水の水 質は地質と地下水環境を反映し、地下水の賦存状態 や流動状態を知る重要な資料となる。さらに、地下 水に含まれる放射性同位体と安定同位体に注目して みると、放射性同位体の崩壊現象は温度や圧力に関 係なく時間のみの関数に依存するため、地下水の涵 養源や年代などを定量的に求めることが期待でき る。

本研究は、こうした地下水の水質および同位体を 利用して岩盤内の地下水の賦存状態とその挙動を流 れの系全体として把握し解明しょうとするもので、 本報告は、そのケーススタディとして地下発電所の 調查坑における湧水を対象にした水質および同位体 組成調査結果をまとめた第一報である。

\section{II 圅查概要}

\section{1 調查個所と地質概要}

調查個所は、岐阜県下木兽川水系根尾川の上流に 位置する揚水式発電所の予定地点である。当発電所 は、地表面下 $350 \sim 400 \mathrm{~m}$ 、水平約 $1,000 \mathrm{~m}$ の山体深 部に計画されており、調査のための横坑が根尾川の 左岸に全長約 $1,200 \mathrm{~m}$ 掘削されている。この調査坑 に湧出している地下水を調查対象とした。

木曾川水系根尾川は、岐阜県と福井県との県境を 東西に走る越美山脈に源を発する。

地下発電所の予定されている付近の根尾川周辺の 地質は砂岩を主体とし、粘板岩を挟在する左門岳累 層および流紋岩からなっており、地質年代的には、 時代未詳中古生層とされている。

地下発電所の予定されている位置に掘削されてい る調査坑の地質は、坑口より $500 \mathrm{~m}$ 付近で左門岳累 層の砂岩から流紋岩に変化している。流紋岩の中で
は大規模な破砕帯は認められず岩質は堅硬である が、比較的節理が発達しており可成りの地下水をと もなう。

岩盤の透水度は、全体としての単純平均は 10.9Lugeon (標準偏差 $\bar{\sigma}=12.5$ Lugeon)であり、地 表面下350 400m の岩盤としては可成り大きな值を 示している。また、坑内に削孔されたボーリング孔 での一部に $30 \mathrm{~kg} / \mathrm{cm}^{2}$ を超える高い水圧を有する地 下水が存在するが、全体としては調查坑およびボー リング孔によるドレーン効果により比較的低い水圧 $\left(1 \sim 2 \mathrm{~kg} / \mathrm{cm}^{2}\right)$ となっている。

図-1に全湧水量の経時変化を示した。坑内湧水は、 積雪期である11月から翌年 2 月に渴水量 $(\mathrm{Q}: 50$ 一 $60 \ell / S)$ となり、融雪、梅雨期から夏季にかけての 4〜7月に豊水量 $(\mathrm{Q}: 100 １ 10 \ell / \mathrm{S})$ となる。

cm)

2 採水時期、位置および分析項目

採水は次に示す時期に 2 回実施した。

第 1 回目：1981年11月 5 日

第 2 回目：1982年11月25日

この両採水時期は図-1に示すように、坑内湧水の 渇水初期に当る。

採水位置は図-2に示す坑内湧水：9ヶ所、地表水 (渓流水)：2ヶ所、計11ヶ所である。この内、No. 1は砂岩中、No. 2 9は流紋岩中の湧水である。また、 No. 2 は発電所予定位置よりは可成り坑口側に位置 しており、坑内ボウリングによるドレーン効果の影 響はほとんど受けていないものと考えられる。No. 10、11は渓流水である。

分析項目は以下のとおりである。 水質 水温、 $\mathrm{pH}$ 、電導度

$$
\begin{aligned}
& \mathrm{Na}^{+}, \mathrm{K}^{+} 、 \mathrm{Ca}^{2+}, \mathrm{Mg}^{2+} 、 \\
& \mathrm{Cl}^{-} 、 \mathrm{SO}_{4}{ }^{2-}, \mathrm{HCO}_{3}{ }^{-} 、 \\
& \mathrm{SiO}_{2}
\end{aligned}
$$$$
\text { 同位体 }{ }^{222} \mathrm{Rn} 、{ }^{3} \mathrm{H}(\mathrm{T}) 、 \mathrm{D} 、{ }^{18} \mathrm{O}
$$$$
\text { その他湧水量 }
$$ 


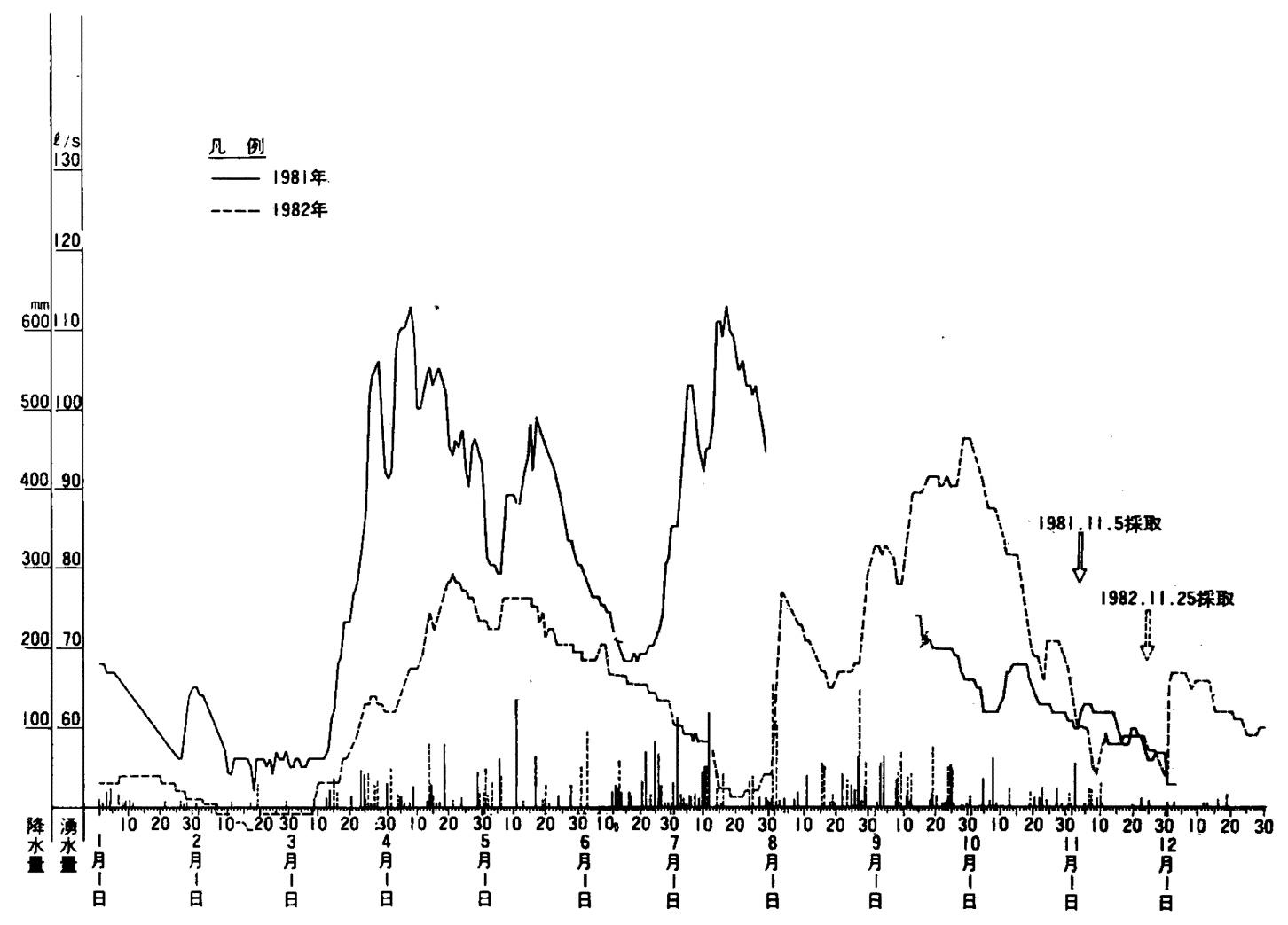

图-1 漂水年の経時变化.

Fig. 1 Variations of the ground water discharge.

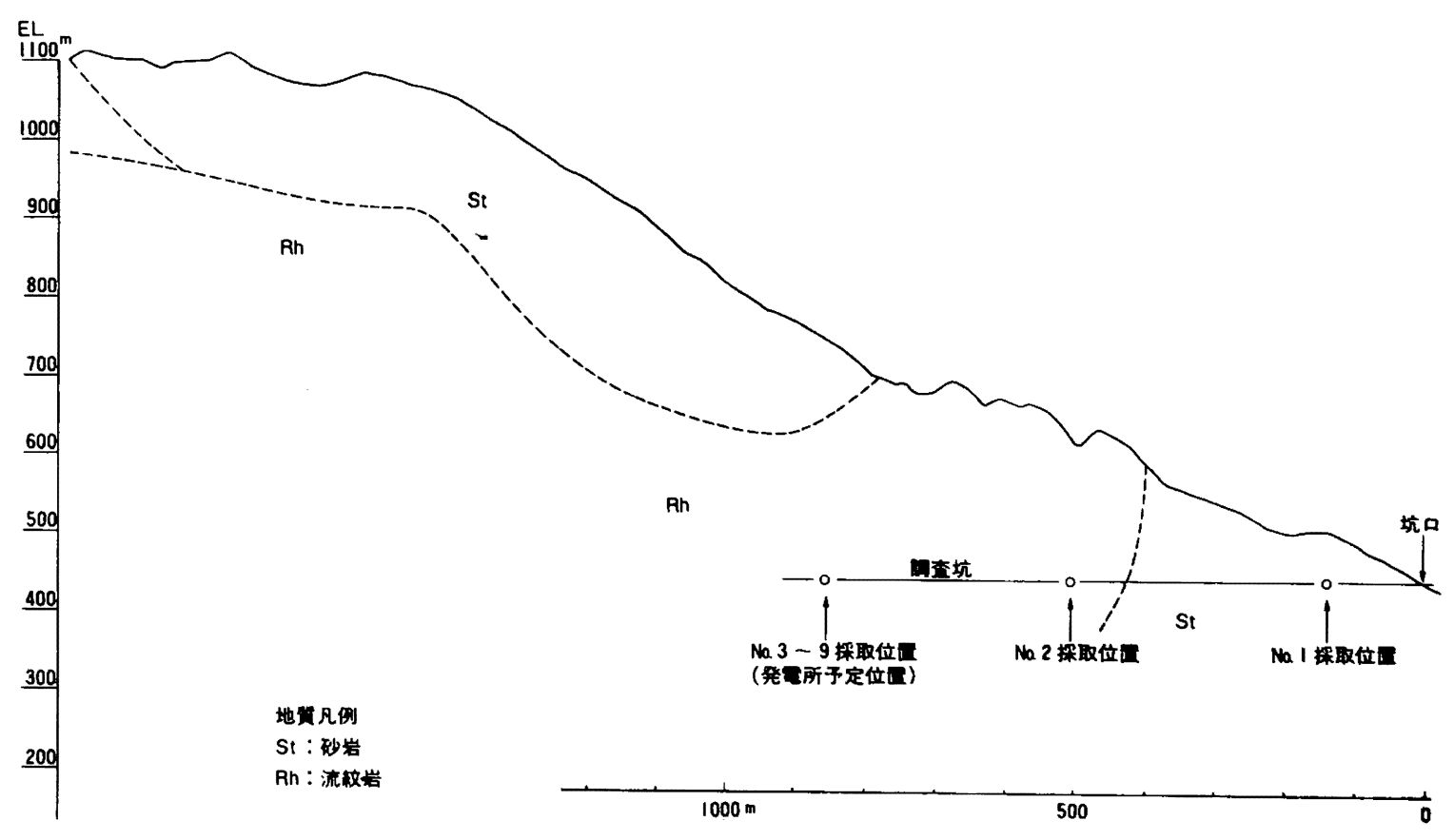

图-2 採水位而.

Fig. 2 Sampling points. 


\section{III 地下水の水質}

水質分析結果を表-1に示す。同表をもとに地下水 の水質についてその特徽を以下に検討する。

\section{1 化学組成}

水質キー・ダイヤグラムおよび水質パターン・ダ イヤグラムは図-3、4のとおりである。

坑内湧水は水質キー・ダイヤグラムの第一領域に 位置しその化学組成は $\mathrm{Ca}\left(\mathrm{HCO}_{3}\right)_{2}$ (アルカリ土類重 炭酸塩) 型であることを示している。全体として第 一領域のほぶ中央に位置しているが、No. 1 は $\mathrm{Ca}^{2+}$ $+\mathrm{Mg}^{2+}$ の優勢側に No. 2 は $\mathrm{K}^{+}+\mathrm{Mg}^{2+}$ の優勢側に それぞれ位置することを特徽とし、両者の化学組成 は他の湧水とや、異なることを示している。また、 溪流水も同じ第一領域に位置するが、や、 $\mathrm{SO}_{4}{ }^{2-}+$ $\mathrm{Cl}^{-}$の優勢側に位置している。

水質パターン・タイヤグラムでは坑内湧水の内 No. 1、2の化学組成が他と異なることがよく分る。 しかし、各組成分の濃度を見ると No. 1の陽イオン が $\mathrm{Ca}^{2+}>\mathrm{Mg}^{2+}>\mathrm{Na}^{+} \gg \mathrm{K}^{+}$、陰イオンが $\mathrm{HCO}_{3}{ }^{-}>$ $\mathrm{SO}_{4}{ }^{2-}>\mathrm{Cl}^{-}$である他は溪流水をも含めてすべて陽 イオンは $\mathrm{Ca}^{2+}>\mathrm{Na}^{+}>\mathrm{Mg}^{2+} \gg \mathrm{K}^{+}$、陰イオンは $\mathrm{HCO}_{3}{ }^{-}>\mathrm{SO}_{4}{ }^{2-}>\mathrm{Cl}^{-}$の関係にあり、陰イオンは No. 1を含めすべて同一の関係にある。

一方、総イオン瀑度をみると、坑内湧水は全体と して1.5〜4.5epm である。No. 1、2およびNo. 6〜9 は3.0〜4.5epm、No. 3〜5は1.5〜2.5epmであるが、 前者の内 No. 1、2は相対的にや、高く、総イオン浱 度は各湧水によりや、異った値を示している。また、 渓流水の綕イオン浱度は坑内湧水よりは低く $1.0 \mathrm{epm}$ 程度である。電気伝導度は坑内湧水が50 $200 \mu_{\mathrm{s}} / \mathrm{cm}$ 、溪流水は40 $\mu_{\mathrm{s}} / \mathrm{cm}$ 程度である。坑 内湧水の電気伝導度についてみると、総イオン浱度 と同様な関係を示している。

さらに、水温は坑内湧水全体として $12^{\circ} \mathrm{C}$ 前後であ
るが、No. 2 は $16^{\circ} \mathrm{C}$ 程度でや、高い。渓流水は気温 の影響を当然受けているとみられるが、気温よりは 比較的高い值を示している。

また、 $\mathrm{pH}$ 值は坑内湧水全体として7.0〜7.4であ るが、No.-2は相対的にや、高い。溪流水は6.9程度 で坑内湧水よりはや、低い。

\section{2 化学組成分相関係数マトリックス}

坑内湧水の各組成分值間の相関係数を求め表-2に 相関マトリックスをまとめた。同表の内、表-2-1は 化学組成をや、異にする No. 1、2を除外ししたもの、 表-2-2はすべての湧水を対象としたものである。

表-2-1では、各化学組成分値間の相関係数は $\mathrm{Cl}^{-}$ との相関を除くと他はすべて非常に高い正相関を示 し、 $\mathrm{Cl}^{-}$を除くいずれの組成分が増加しても他の組 成分は一義的に増加することを示している。このこ とは、No. 1、2を除く坑内湧水は $\mathrm{CO}_{2}$ に豊む地下水 が岩石に作用し $\mathrm{Na}^{+} 、 \mathrm{~K}^{+} 、 \mathrm{Ca}^{2+} 、 \mathrm{Mg}^{2+}$ などを溶 出させ $\mathrm{CO}_{2}$ は $\mathrm{HCO}_{3}{ }^{-}$に変化する岩石一水相互作用 （三木・吉沢、1979）による化学組成変化が支配的で あり、短時間で浸透した地表水など比較的新しい地 下水が可成りの量混入していることを示唆している ものと考えられる。この No. 1、2を除く湧水個所は、 前述のように透水性が高く調查坑およびボウリング 孔によるドレーン効果によって地下水圧は低下して おり比較的新しい地下水が混入しやすい条件となっ ている。

一方、すべての湧水を対象とした表-2-2の相関係 数は全体として表-2-1よりは小さい。しかし、 $\mathrm{Cl}^{-}$ との相関を除けば表-2-1と同様にすべて正相関であ る。このことは、No. 1、2についてもその化学組成 は岩石一水相互作用による地下水中の化学組成変化 が支配的であると考えてよいことを示しているもの と思われる。 
泰-1-1 水暂分析拮果 (1981．11)

Table 1.1 Result of chemical analyses (1981. 11)

\begin{tabular}{|c|c|c|c|c|c|c|c|}
\hline $\begin{array}{l}\text { 採 } \\
\mathrm{Na} \\
\end{array}$ & $\begin{array}{l}\text { 位 } \\
\text { 位 }\end{array}$ & $\begin{array}{l}\text { 置 } \\
\text { 置 }\end{array}$ & $\begin{array}{c}\text { 気 温 } \\
\mathrm{T} \\
\end{array}$ & $\begin{array}{c}\text { 水 温 } \\
\mathrm{Tw}\end{array}$ & p H & $\begin{array}{c}\text { 電觎度 } \\
\text { EC }\end{array}$ & $\begin{array}{c}\text { 涌水量 } \\
\mathbf{Q} \\
\end{array}$ \\
\hline & & & $\left({ }^{\circ} \mathrm{C}\right)$ & $\left({ }^{\circ} \mathrm{C}\right)$ & & $(\mu \mathrm{s} / \mathrm{cm})$ & $(\ell / s)$ \\
\hline 1 & TD $160 \mathrm{~m}$ & & 12.9 & 12.2 & 7. 2 & 130 & 0.070 \\
\hline 2 & TD $585 \mathrm{~m}$ & & 12.8 & 16.2 & 7. 4 & 180 & 0.30 \\
\hline 3 & TD $865 \mathrm{~m}$ & & 12.4 & 11.3 & 7.1 & 60 & 0.046 \\
\hline 4 & Na 13 孔 & （水平） & 12.3 & 11.9 & 7. 1 & 84 & 0.47 \\
\hline 5 & №. 12 孔 & $(" \prime)$ & 13.6 & 13.2 & 7. 0 & 84 & 2. 34 \\
\hline 6 & Na 16 孔 & $(" \prime)$ & 12.3 & 12.8 & 7. 2 & 140 & 6.64 \\
\hline 7 & Na 7 孔 & $(" \prime)$ & 11.8 & 12.2 & 7. 2 & 128 & 0.20 \\
\hline 8 & Na 2 孔 & （下向） & 12.0 & 11.9 & 7. 2 & 123 & 1.20 \\
\hline 9 & Na 15 孔 & （水平） & 12.2 & 11.2 & 7. 2 & 105 & 6.10 \\
\hline 10 & 上流 沢 & & 8. 9 & 10.9 & 6. 9 & 39 & - \\
\hline 11 & 廻り谷沢 & & 8. 6 & 10.5 & 7. 1 & 30 & - \\
\hline
\end{tabular}

表-1-2 水筫分析喆果 (1982. 11)

Table-1-2 Result of chemical analyses (1982. 11)

\begin{tabular}{|c|c|c|c|c|c|c|c|c|}
\hline $\begin{array}{l}\text { 採 } \\
\mathrm{Na}\end{array}$ & 水 & $\begin{array}{l}\text { 位 } \\
\text { 位 }\end{array}$ & $\begin{array}{l}\text { 㯰 } \\
\text { 置 }\end{array}$ & $\begin{array}{c}\text { 気 } \text { 温 }^{T} \\
T\end{array}$ & $\begin{array}{c}\text { 水 温 } \\
\mathrm{Tw}\end{array}$ & $\mathrm{pH}$ & $\begin{array}{c}\text { 電尊度 } \\
\text { E C }\end{array}$ & $\begin{array}{c}\text { 涌水量 } \\
\mathbf{Q}\end{array}$ \\
\hline & & & & $\left({ }^{\circ} \mathrm{C}\right)$ & $\left({ }^{\circ} \mathrm{C}\right)$ & & $(\mu \mathrm{s} / \mathrm{cm})$ & $(\ell / s)$ \\
\hline 1 & $\mathrm{~T}$ & $160 \mathrm{~m}$ & 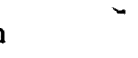 & 13. 6 & 12.0 & 7. 2 & 138 & 0.042 \\
\hline 2 & & $585 \mathrm{~m}$ & & 12.8 & 15.8 & 7. 3 & 181 & 0.28 \\
\hline 3 & & $865 \mathrm{~m}$ & & 12.4 & 10.9 & 7.1 & 58 & 0.043 \\
\hline 4 & $\mathrm{Na}$ & 13 孔 & （水平） & 12.3 & 11.7 & 7.2 & 90 & 0.64 \\
\hline 5 & $\mathrm{Na}$ & 12 孔 & $(" \prime)$ & 14.1 & 12.9 & 7. 2 & 86 & 2.35 \\
\hline 6 & Na & 16 孔 & $(" \prime)$ & 11.8 & 12.6 & 7.2 & 131 & 4. 50 \\
\hline 7 & $\mathrm{Na}$ & 7 孔 & $(1)$, & 12.5 & 11.9 & 7. 2 & 130 & 0.16 \\
\hline 8 & & 2 孔 & (下向 ) & 13.4 & 11.6 & 7. 4 & 124 & 1.27 \\
\hline 9 & & 15 孔 & （水平） & 12.6 & 10.8 & 7. 2 & 107 & 5.70 \\
\hline 10 & & 流 沢 & & 3. 3 & 8.9 & 6.9 & 49 & - \\
\hline 11 & & り谷沢 & & 3.4 & 8.7 & 6.9 & 39 & - \\
\hline
\end{tabular}


表-1-3 水䨢分析落果(1981，11)

Table-1-3 Result of chemical analyses (1981. 11)

\begin{tabular}{|c|c|c|c|c|c|c|c|c|c|c|c|c|c|c|}
\hline \multirow[b]{2}{*}{$\begin{array}{l}3 \\
\text { n }\end{array}$} & \multirow[b]{2}{*}{ * } & \multirow[b]{2}{*}{$\begin{array}{l}\text { 位 } \\
\text { 位 }\end{array}$} & \multirow[b]{2}{*}{ a } & \multirow[b]{2}{*}{$\mathrm{N}_{\mathbf{a}}+$} & \multirow[b]{2}{*}{$\mathrm{K}^{+}$} & \multirow[b]{2}{*}{$\mathrm{Ca}^{2+}$} & \multirow[b]{2}{*}{$\mathrm{Mg}^{2+}$} & \multirow[b]{2}{*}{$\mathrm{Cl}^{-}$} & \multirow[b]{2}{*}{ So. ${ }^{2-}$} & \multirow[b]{2}{*}{$\mathrm{HCO}_{4}^{-}$} & \multicolumn{2}{|c|}{ 位：ppm } & \multicolumn{2}{|c|}{ )内仕当䡒: epm } \\
\hline & & & & & & & & & & & $\mathrm{SiO}_{2}$ & $\Sigma \mathrm{Ca}$ & IAn & rion \\
\hline & & & & $(0.161)$ & $'(0.02)$ & $(1.218)$ & $(0.461)$ & $(0.042)$ & $(0.289)$ & $(1.580)$ & & $(1.860)$ & $(1.911)$ & $(3.711)$ \\
\hline \multirow[t]{2}{*}{1} & \multicolumn{3}{|c|}{ TD $160 \mathrm{~m}$} & 3.7 & 0.8 & 24.4 & 5.6 & 1.5 & 13.9 & 96.4 & 8.8 & & & \\
\hline & & & & $(0.726)$ & $(0.02)$ & ( 1.597$)$ & $(0.115)$ & $(0.056)$ & $(0.187)$ & $(2.032)$ & & $(2.458)$ & $(2.275)$ & $(4.733)$ \\
\hline \multirow[t]{2}{*}{2} & \multicolumn{3}{|c|}{ TD $585 \mathrm{~m}$} & 16.7 & 0.8 & 32.0 & 1.4 & 2.0 & 9.0 & 124.0 & 26.1 & & & \\
\hline & & & & $(0.113)$ & $(0.008)$ & $(0.544)$ & $(0.058)$ & $(0.037)$ & $(0.119)$ & $(0.587)$ & & $(0.723)$ & $(0.743)$ & $(1.466)$ \\
\hline \multirow[t]{2}{*}{3} & TD & $865 \mathrm{~m}$ & & 2.6 & 0.3 & 10.0 & 0.7 & 1.3 & 5.7 & 35.8 & 9.8 & & & \\
\hline & & & & $(0.17)$ & $(0.01)$ & $(0.873)$ & $(0.066)$ & $(0.039)$ & $(0.142)$ & $(0.96)$ & & $(1.119)$ & $(1.141)$ & $(2.260)$ \\
\hline \multirow[t]{2}{*}{4} & S 1 & 13 凡 & (水平) & 3.9 & 0.4 & 17.5 & 0.8 & 1.4 & 6.8 & 58.6 & 11.1 & & & \\
\hline & & & & $(0.191)$ & $(0.01)$ & $(0.813)$ & $(0.082)$ & $(0.039)$ & $(0.131)$ & $(0.933)$ & & $(1.096)$ & $(1.103)$ & $(2.199)$ \\
\hline \multirow[t]{2}{*}{5} & th 1 & 12 凡 & $(\cdot)$ & 4.4 & 0.4 & 16.3 & 1.0 & 1.4 & 6.3 & 56.9 & 11.6 & & & \\
\hline & & & & $(0.23)$ & $(0.015)$ & $(1.617)$ & $(0.082)$ & $(0.042)$ & $(0.171)$ & $(1.770)$ & & $(1.044)$ & $(1.983)$ & $(3.927)$ \\
\hline \multirow[t]{2}{*}{6} & No 1 & 16 भ & $(-)$ & 5.3 & 0.6 & 32.4 & 1.0 & 1.5 & 8.2 & 108.0 & 13.5 & & & \\
\hline & & & & $(0.248)$ & $(0.013)$ & $(1.437)$ & $(0.099)$ & $(0.039)$ & $(0.202)$ & $(1.603)$ & & $(1.797)$ & $(1.844)$ & $(3.641)$ \\
\hline \multirow[t]{2}{*}{7} & tho & $7 \mathrm{fl}$ & $(-)$ & 5.7 & 0.5 & 28.8 & 1.2 & 1.4 & 9.7 & 97.8 & 12.2 & & & \\
\hline & & & & $(0.217)$ & $(0.013)$ & $(1.432)$ & $(0.09)$ & $(0.042)$ & $(0.162)$ & $(1.591)$ & & $(1.752)$ & $(1.795)$ & $(3.547)$ \\
\hline \multirow[t]{2}{*}{8} & we & 2 it & (下向) & 5.0 & 0.5 & 28.7 & 1.1 & 1.5 & 7.8 & 97.1 & $12.6 \bullet$ & & & \\
\hline & & & & $(0.178)$ & $(0.013)$ & $(1.228)$ & $(0.074)$ & $(0.045)$ & $(0.117)$ & $(1.339)$ & & $(0.493)$ & $(1.501)$ & $(2.994)$ \\
\hline \multirow[t]{2}{*}{9} & No 1 & & （水平） & 4.1 & 0.5 & 24.6 & 0.9 & 1.6 & 5.6 & 81.7 & 11.6 & & & \\
\hline & & & & $(0.087)$ & $(0.008)$ & $(0.384)$ & $(0.049)$ & $(0.039)$ & $(0.110)$ & $(0.385)$ & & $(0.528)$ & $(0.534)$ & $(1.062)$ \\
\hline \multirow[t]{2}{*}{10} & 上 & 部 & & 21 & 0.3 & 7.7 & 0.0 & 1.4 & 5.3 & 23.5 & 8.8 & . & & \\
\hline & & & & $(0.100)$ & $(0.008)$ & $(0.304)$ & $(0.033)$ & $(0.039)$ & $(0.054)$ & $(0.320)$ & & $(0.445)$ & $(0.413)$ & $(0.858)$ \\
\hline 11 & a & 谷关 & & 23 & 0.3 & 6.1 & 0.4 & 1.4 & 26 & 19.5 & 9.0 & & & \\
\hline
\end{tabular}

表-1-4 水算分析洁果 (1982. 11)

Table-1-4 Result of chemical analyses (1982. 11)

\begin{tabular}{|c|c|c|c|c|c|c|c|c|c|c|c|c|c|c|}
\hline 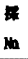 & * & 位 & $\frac{a}{a}$ & $\mathrm{Na}{ }^{*}$ & $\mathbf{K}^{+}$ & $\mathrm{Ca}^{2+}$ & $\mathrm{Mg}^{2+}$ & $\mathrm{Cl}^{-}$ & So.2- & $\mathrm{HCO}_{3}^{-}$ & $\mathrm{SiO}_{2}$ & $\Sigma \mathrm{Ca}$ & $\Sigma A n$ & Iion \\
\hline & & & & $(0.139)$ & $(0.015)$ & $(1.168)$ & $(0.650)$ & $(0.042)$ & $(0.281)$ & $(1.537)$ & & $(1.872)$ & $(1.860)$ & $(3.832)$ \\
\hline \multirow[t]{2}{*}{1} & \multicolumn{3}{|c|}{ TD $160 \mathrm{~m}$} & 3.2 & 0.6 & 23.4 & 7.9 & 1.5 & 13.5 & 93.8 & 8.4 & & & \\
\hline & & & & $(0.678)$ & $(0.013)$ & $(1.362)$ & $(0.148)$ & $(0.059)$ & $(0.190)$ & $(1.880)$ & & $(2.201)$ & $(2.229)$ & $(4.430)$ \\
\hline \multirow[t]{2}{*}{2} & \multicolumn{3}{|c|}{ TD $585 \mathrm{~m}$} & 15.6 & 0.5 & 27.3 & 1.8 & 2.1 & 0.1 & 120.8 & 25.3 & & & \\
\hline & & & & $(0.108)$ & $(0.008)$ & $(0.574)$ & $(0.066)$ & $(0.045)$ & $(0.127)$ & $(0.593)$ & & $(0.757)$ & $(0.765)$ & $\left(\begin{array}{ll}1.522 & 2\end{array}\right)$ \\
\hline \multirow[t]{2}{*}{3} & \multicolumn{3}{|c|}{ TD $865 \mathrm{~m}$} & 2.5 & 0.3 & 11.5 & 0.8 & 1.6 & 6.1 & 36.2 & 8.8 & & & \\
\hline & & & & $(0.174)$ & $(0.01)$ & $(0.928)$ & $(0.082)$ & $(0.039)$ & $(0.160)$ & $(1.026)$ & & $(1.194)$ & $(1.225)$ & $(2.419)$ \\
\hline \multirow[t]{2}{*}{4} & 1 & & (*平) & 4.0 & 0.4 & 18.6 & 1.0 & 1.4 & 0.7 & 62.6 & 11.4 & & & \\
\hline & & & & $(0.191)$ & $(0.01)$ & $(0.988)$ & $(0.099)$ & $(0.039)$ & $(0.135)$ & $(0.933)$ & & $(1.088)$ & $(1.078)$ & $(2.166)$ \\
\hline \multirow[t]{2}{*}{5} & mo 1 & & $(-)$ & 4.4 & 0.4 & 15.8 & 1.2 & 1.4 & 6.5 & 66.9 & 11.4 & & & \\
\hline & & & & $(0.23)$ & $(0.013)$ & $(1.667)$ & $(0.082)$ & $(0.045)$ & $(0.183)$ & $(1.747)$ & & $(1.982)$ & $(1.975)$ & $(3.967)$ \\
\hline \multirow[t]{2}{*}{6} & M.le & & $(=)$ & 5.3 & 0.5 & 33.4 & 1.0 & 1.6 & 8.8 & 106.6 & 13.5 & & & \\
\hline & & & & $(0.252)$ & $(0.013)$ & $(1.447)$ & $(0.123)$ & $(0.042)$ & $(0.237)$ & $(1.600)$ & & $(1.835)$ & $(1.879)$ & $(3.711)$ \\
\hline \multirow[t]{2}{*}{7} & m 7 & $\mathrm{fl}$ & $(-1)$ & 5.8 & 0.5 & 29.0 & 1.5 & 1.5 & 11.4 & 97.6 & 12.2 & & & \\
\hline & & & & $(0.204)$ & $(0.013)$ & $(1.447)$ & $(0.09)$ & $(0.042)$ & $(0.171)$ & $(1.537)$ & & $(1.754)$ & $(1.750)$ & $(3.504)$ \\
\hline \multirow[t]{2}{*}{8} & 2 & 丹 & （下句） & 4.7 & 0.5 & 29.0 & 1.1 & 1.5 & 8.2 & 93.8 & 13.1 & & & \\
\hline & & & & $(0.178)$ & $(0.013)$ & $(1.263)$ & $(0.074)$ & $(0.045)$ & $(0.140)$ & $(1.329)$ & & $(1.528)$ & $(1.514)$ & $(3.042)$ \\
\hline \multirow[t]{2}{*}{$\theta$} & 15 & & ( & 4.1 & 0.6 & 25.3 & 0.8 & 1,6 & 6.7 & 81.1 & - & & & \\
\hline & & & & $(0.100)$ & $(0.013)$ & $(0.449)$ & $(0.066)$ & $(0.076)$ & $(0.117)$ & $(0.426)$ & & $\left(\begin{array}{ll}0.6 & 28\end{array}\right)$ & $(0.619)$ & $(1.247)$ \\
\hline \multirow[t]{2}{*}{10} & 上 & $R$ & & 2.3 & 0.6 & 9.0 & 0.8 & 2.7 & 5.6 & 26.0 & - & & & \\
\hline & & & & $(0.122)$ & $(0.300)$ & $(0.300)$ & $(0.041)$ & $(0.065)$ & $(0.079)$ & $(0.351)$ & & $(0.482)$ & $(0.495)$ & $(0.977)$ \\
\hline 11 & 周り & 谷布 & & 28 & 0.4 & 6.2 & 0.5 & 2.3 & 3.8 & 21.4 & - & & & \\
\hline
\end{tabular}




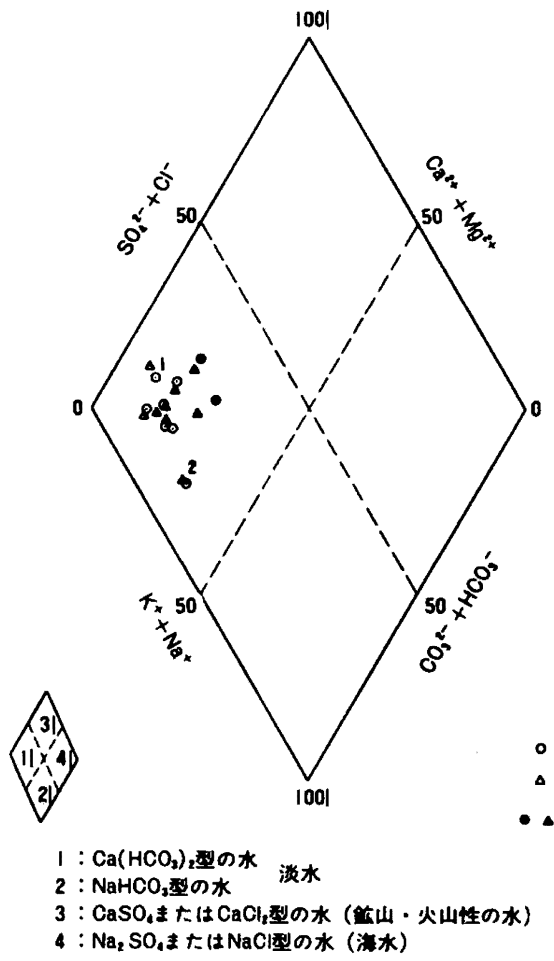

图-3 水贯キー・ダイヤグラム.

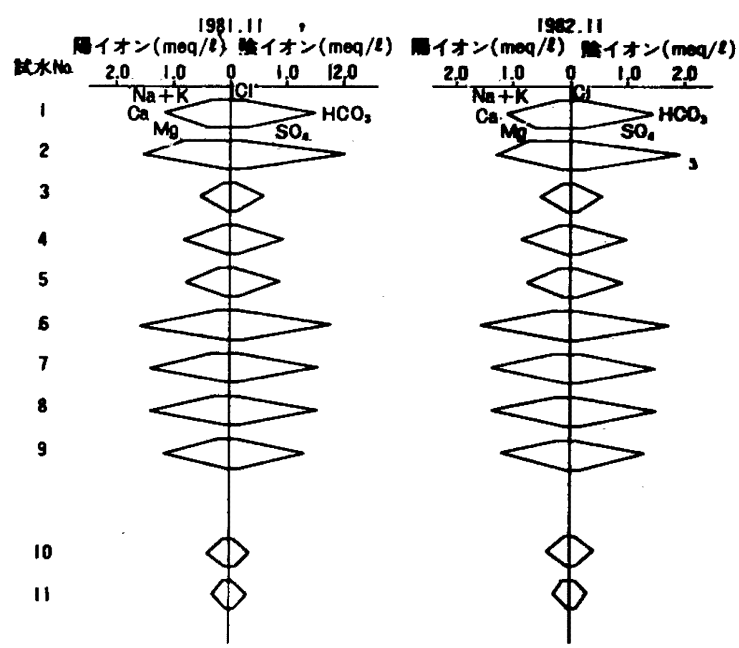

図-4 水貿バターン・ダイヤグム。

Fig. 4 Pattern diagrams for water quality.

Fig. 3 Key diagrams for water quality.

表-2-1 化学租成分相閶保数マトリックス(除 No. 1、2)

Table-2-1 The correlation coefficient matrix on chemical composition of the groundwater discharge. (Except No. 1, 2 of discharge)

\begin{tabular}{|c|c|c|c|c|c|c|c|c|c|}
\hline & $\mathrm{Na}^{+}$ & $\mathrm{K}^{+}$ & $\mathrm{Ca}^{2+}$ & $\mathrm{Mg}^{2+}$ & $\mathrm{Cl}^{-}$ & $\mathrm{SO}_{4}{ }^{2-}$ & $\mathrm{HCO}_{3}^{-}$ & $\mathrm{SiO}_{2}$ & EC \\
\hline $\mathrm{Na}^{+}$ & 1.000 & 0.731 & 0.916 & 0.855 & -0.340 & 0.850 & 0.939 & 0.883 & 0.810 \\
\hline $\mathrm{K}^{+}$ & & 1.000 & 0.822 & 0.598 & 0.221 & 0.621 & 0.811 & 0.579 & 0.949 \\
\hline $\mathrm{Ca}^{2+}$ & & & 1.000 & 0.749 & -0.303 & 0.847 & 0.997 & 0.921 & 0.989 \\
\hline $\mathrm{Mg}^{2+}$ & & & & 1.000 & 0.263 & 0.902 & 0.773 & 0.719 & 0.817 \\
\hline $\mathrm{Cl}^{-}$ & & & & & 1.000 & -0.274 & -0.330 & -0.602 & -0.321 \\
\hline $\mathrm{SO}_{4}^{2-}$ & & & & & & 1.000 & 0.829 & 0.742 & 0.857 \\
\hline $\mathrm{HCO}_{3}^{-}$ & & & & & & & 1.000 & 0.930 & 0.889 \\
\hline $\mathrm{SiO}_{2}$ & & & & & & & & 1.000 & 0.859 \\
\hline
\end{tabular}

注）除兴 1,2 
表-2-2 化学蝴成分相阙保数マトリックス（全資料）

Table-2-2 The correlation coefficient matrix on chemical composition of the groundwater discharge. (All samples)

\begin{tabular}{|c|c|c|c|c|c|c|c|c|c|}
\hline & $\mathrm{Na}^{+}$ & $\mathrm{K}^{+}$ & $\mathrm{Ca} \mathrm{a}^{2+}$ & $\mathrm{Mg}^{2+}$ & $\mathrm{Cl}^{-}$ & $\mathrm{SO}_{4}{ }^{2-}$ & $\mathrm{HCO}_{3}-$ & $\mathrm{SiO}_{2}$ & E C \\
\hline $\mathrm{Na}^{+}$ & 1.000 & 0.522 & 0.551 & 0.069 & 0.287 & 0.297 & 0.677 & 0.978 & 0.758 \\
\hline $\mathrm{K}^{+}$ & & 1.000 & 0.401 & 0.533 & 0.233 & 0.722 & 0.763 & 0.437 & 0.771 \\
\hline $\mathrm{Ca}^{2+}$ & & & 1.000 & 0.232 & -0.388 & 0.669 & 0.971 & 0.585 & $\begin{array}{llll}0.9 & 2 & 1\end{array}$ \\
\hline $\mathrm{Mg}^{2+}$ & & & & 1.000 & -0.093 & 0.782 & 0.349 & -0.095 & 0.391 \\
\hline $\mathrm{Cl}^{-}$ & & & v & & 1.000 & -0.153 & -0.084 & 0.172 & -0.008 \\
\hline $\mathrm{SO}_{4}^{2-}$ & & & & & & & 0.734 & 0.227 & 0.745 \\
\hline $\mathrm{HCO}_{3}^{-}$ & & & & & & & 1.000 & 0.684 & 0.985 \\
\hline $\mathrm{SiO}_{2}$ & & & & & & & & 1.000 & 0.621 \\
\hline
\end{tabular}

\section{N 地下水の同位体組成}

同位体分析結果を表 $に$ 示す。同表をもとに地下 水の同位体組成の特徴を以下に検討する。

\section{1 ラドン $\left({ }^{222} \mathrm{Rn}\right)$}

坑内湧水の ${ }^{222} \operatorname{Rn}$ 濃度は全体として $(1 \sim 25) \times$ $10^{-10} \mathrm{Ci} / \ell$ の值を示すが、大半は $(20 \sim 25) \times 10^{-10}$ $\mathrm{Ci} / \ell$ でNo. 1、5が相対的に小さい。渓流水の ${ }^{222} \mathrm{Rn}$ 濃度は極めて小さい。

国5は1981年と82年との関係を示すものである が、82年は81年に比べその濃度は減少傾向にあるこ とが分る。

一般に、 ${ }^{222} \mathrm{Rn}$ の基本的親核種である ${ }^{238} \mathrm{U}$ は地層 ごとに固有な含有量をもち、その娘核種である ${ }^{226} \mathrm{Ra}$ は地層の構成粒子とその表面への吸着沈汼物

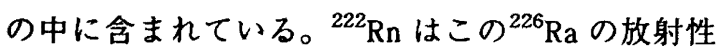
崩壊により生ずるものであるが、 ${ }^{222} \mathrm{Rn}$ の一部は周 辺の地下水へ移行する(建設産業調査会、1979)。こ の場合、地下水の流速が一定ならば、この移行量と 放射性崩壊量とは平衡し ${ }^{222} \mathrm{Rn}$ 濃度は一定になるで
あろうが、流速が変化すると ${ }^{222} \mathrm{Rn}$ の半減期 $(3,829$ 日）が非常に小さいことを反映し変化するものと考 えられる。 ${ }^{222} \mathrm{Rn}$ 濃度の異なる地下水の混入などが なく地下水の流速のみが速くなれば、 ${ }^{222} \mathrm{Rn}$ 濃度は 大きくなるであろう。

図-6は ${ }^{222} \mathrm{Rn}$ 濃度と坑内の湧水量との変化の関係 をまとめたものであるが、横軸に湧水量の1981年と 82 年との比、縦軸に ${ }^{222} \mathrm{Rn}$ 濃度の 1981 年と 82 年との 比を示してある。資料数が少なく信頼性にや、疑問 はあるが、両者は比較的高い負相関 $(-0.634)$ を示 している。湧水量の増加は地下水流速の增大を伴い、 ${ }^{222} \mathrm{Rn}$ 濃度と湧水量との関係は正相関を示すものと 思われたが、図6は逆傾向を示している。このこと は、坑内湧水には比較的短時間で、浸透した地表水 など ${ }^{222} \mathrm{Rn}$ 濃度の小さな地下水の混入があること、 また、1981年と82年とではその混入の割合が変化し ていることを示唆しているものと考えられる。

2 トリチウム $(\mathrm{T})$

坑内湧水の T 濃度は No. 2を除いて10 20 T. U の值を示す。No. 2は1981年 : 1.8 T. U、82年 : 5.4 
表-3-1 同位体粗成分析轺果 (1981．11)

Table-3-1 Result of isotopic composition analyses (1981. 11)

\begin{tabular}{|c|c|c|c|c|c|c|c|}
\hline $\begin{array}{l}\text { 採 } \\
\mathrm{Na}\end{array}$ & 水 & $\begin{array}{l}\text { 位 } \\
\text { 位 }\end{array}$ & $\begin{array}{l}\text { 置 } \\
\text { 置 }\end{array}$ & $\begin{array}{c}\text { ラドン } \\
\text { R n }\end{array}$ & $\begin{array}{c}\text { 水 素 } \\
\delta \mathrm{D}\end{array}$ & $\begin{array}{c}\text { 酸 素 } \\
8^{18} \mathrm{O}\end{array}$ & $\begin{array}{c}\text { トリチゥム } \\
\mathrm{T}\end{array}$ \\
\hline & & & & $(\times 10 \mathrm{Ci} / \ell)$ & $(\%)$ & $(\%)$ & $(T U)$ \\
\hline 1 & $T D$ & $160 \mathrm{~m}$ & & 0.8 & -51.7 & -8.4 & $14.9 \pm 1.8$ \\
\hline 2 & TD & $585 \mathrm{~m}$ & & 19.5 & -54.4 & -8.7 & $1.8 \pm 0.3$ \\
\hline 3 & $\mathrm{TD}$ & $865 \mathrm{~m}$ & & 6.4 & -54.3 & -8.8 & $12.6 \pm 1.6$ \\
\hline 4 & $\mathrm{Na}$ & 13 孔 & （水平） & 24.8 & -55.5 & -8.7 & $14.4 \pm 1.8$ \\
\hline 5 & No. & 12 丹 & $(" \prime)$ & 13.6 & -56.8 & -9.0 & $14.2 \pm 1.8$ \\
\hline 6 & $\mathrm{Na}$ & 16 孔 & $(" \prime)$ & 21.7 & -54.1 & -8.4 & $16.1 \pm 2.0$ \\
\hline 7 & $\mathrm{Na}$ & 7 孔 & $(" \prime)$ & 25.4 & -53.9 & -8.7 & $13.4 \pm 1.7$ \\
\hline 8 & $\mathrm{Na}$ & 2 孔 & （下向 ） & 23.6 & -54.3 & -8.6 & $15.7 \pm 1.9$ \\
\hline 9 & $\mathrm{Na}$ & 15 孔 & (水平) & 23.0 & -53.8 & -8.7 & $17.9 \pm 2.2$ \\
\hline 10 & 上 & 流 沢 & & 0.2 & -53.0 & -8.2 & $15.2 \pm 1.9$ \\
\hline 11 & 廻 & り谷沢 & & 0.3 & -55.1 & -8.8 & $11.4 \pm 1.5$ \\
\hline
\end{tabular}

表-3-2 同位体相成分析桔果 (1982. 11)

Table-3-2 Result of isotopic composition analyses (1982.11)

\begin{tabular}{|c|c|c|c|c|c|c|c|}
\hline $\begin{array}{l}\text { 採 } \\
\mathrm{Na}\end{array}$ & 水 & $\begin{array}{l}\text { 位 } \\
\text { 位 }\end{array}$ & $\begin{array}{l}\text { 置 } \\
\text { 置 }\end{array}$ & $\begin{array}{c}\text { ラドン } \\
\text { Rn }\end{array}$ & $\begin{array}{c}\text { 水 素 } \\
\delta \mathrm{D}\end{array}$ & $\begin{array}{c}\text { 酸 素 } \\
\delta^{18} \mathrm{O}\end{array}$ & $\begin{array}{c}\text { トリチゥム } \\
\mathrm{T}\end{array}$ \\
\hline & & & & $(\times 10 \mathrm{Ci} / \ell)$ & $(\%)$ & $(\%)$ & $(\mathrm{TU})$ \\
\hline 1 & & $160 \mathrm{~m}$ & & 0.7 & -52.0 & -8.4 & $18.3 \pm 2.1$ \\
\hline 2 & & $585 \mathrm{~m}$ & & 18.6 & - & - & $5.4 \pm 0.7$ \\
\hline 3 & & $865 \mathrm{~m}$ & & 5. 1 & -57.2 & -8.9 & $16.3 \pm 1.9$ \\
\hline 4 & & 13 孔 & (水平) & 22.0 & - & - & $16.5 \pm 1.9$ \\
\hline 5 & & 12 孔 & $(" n)$ & 11.3 & -58.0 & -9.2 & $16.2 \pm 1.9$ \\
\hline 6 & & 16 孔 & $(" \prime)$ & 18.0 & -53.9 & -8.6 & $14.7 \pm 1.8$ \\
\hline 7 & & 7 孔 & $(" \prime)$ & 25.7 & - & - & $15.1 \pm 1.8$ \\
\hline 8 & & 2 孔 & (下向 ) & 23.6 & - & - & $17.2 \pm 2.0$ \\
\hline 9 & & 15 孔 & (水平) & 22.3 & -56.2 & -8.7 & $20.2 \pm 2.4$ \\
\hline 10 & & 流 沢 & & 0.02 & -49.8 & -7.8 & $12.8 \pm 1.5$ \\
\hline 11 & & り谷沢 & & 0 & -53.7 & -8.3 & $15.9 \pm 1.9$ \\
\hline
\end{tabular}




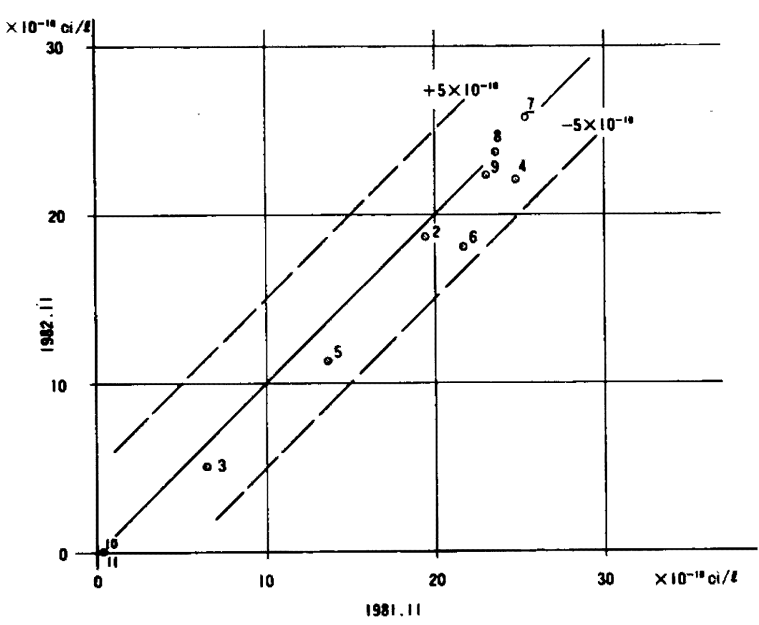

図-5 ラドン $\left({ }^{222} \mathrm{Rn}\right)$ の变化.

Fig. 5 Variation of ${ }^{222} \mathrm{Rn}$ composition.

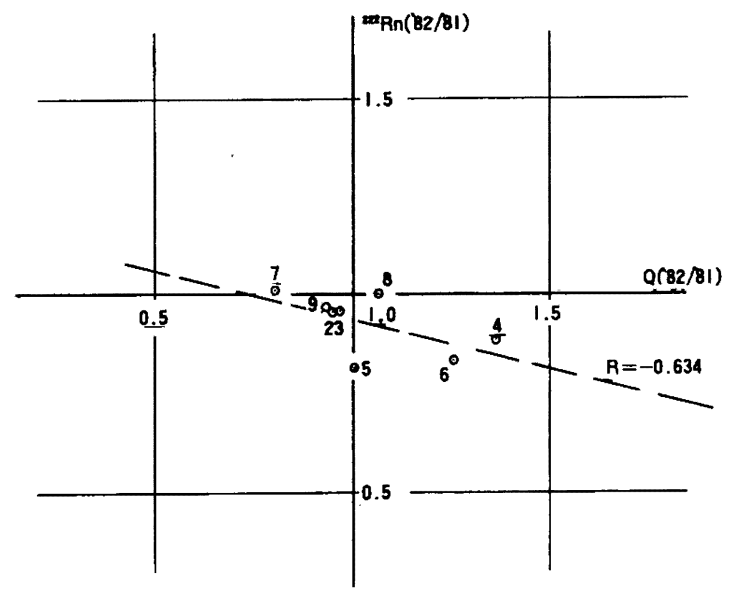

图-6 ラドン $\left({ }^{222} \mathrm{Rn}\right)$ と汤水年との目係.

Fig. 6 Relation between ${ }^{222} \mathrm{Rn}$ composition and the ground water discharge.

T. Uで他の湧水に比べ著しく小さい。溪流水を T 浱度も10２0 T. Uの値を示し、No.2を除く坑内湧 水と同程度で影著な差は認められない。

一般に、降水中の T 搌度は1953年までは約 $10 \mathrm{~T}$. Uの天然レベルに保たれていたが、1953年以降、大 気中で行なわれた熱核爆発実験によって大量の人工 トリチウムが、とくに成層圈において大気中に放出 され、その渡度は急增した。その後、降水中の $\mathrm{T}$
濃度は1963年にピークに達し以後は指数関数的に減 少し現在ほぶ天然レベルに戻っている（榧根・田 中・嶋田、1980)。

前述したようにNo. 2を除く坑内湧水と溪流水の T源度が琹ら゙同程度の10 20 T. Uの值を示してい るが、前者は降水中の T濃度が天然レベルより増 大していた時期 (1953年以降)の降水を起源とし地下 水としての流動に伴い放射性崩壊によりその濃度が 隇少し現在に至っていること、後者はほぶ天然のレ ベルに戻った最近の降水であることをそれぞれ示し ているものと考えられる。

困-7は1981年と 82 年との関係を示すものである が、82年は 81 年に比べその濃度は増加傾向にあるこ とが分る。

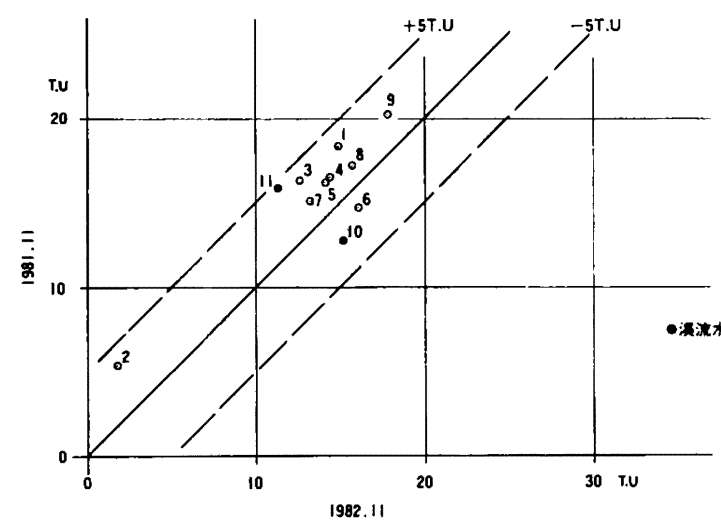

困-7 トリチウム $(\mathrm{T})$ の変化.

Fig. 7 Variation of $\mathrm{T}$ composition.

図-8は $\mathrm{T}$ 濃度と坑内の湧水量との変化の関係をま とめたものであり、横軸に湧水量の1981年と82年と の比、絴軸に T 濃度の1981年と82年との比を示し てある。同図は坑内湧水の大半の $\mathrm{T}$ 濃度は湧水量 に関係なく10２0\%増加していることを示してい る。ことことは坑内湧水の大半は降水中の $\mathrm{T}$ 濃度 が増加しつつあった時期 (1953〜1963)の降水を起源 としていることを示唆するものと考えられる。この 
場合、比較的短時間で浸透した地表水などの混入を 受けてもその T 濃度が湧水とほ心゙同程度であるな らば坑内湧水の T 濃度はほとんど影響を受けない であろう。

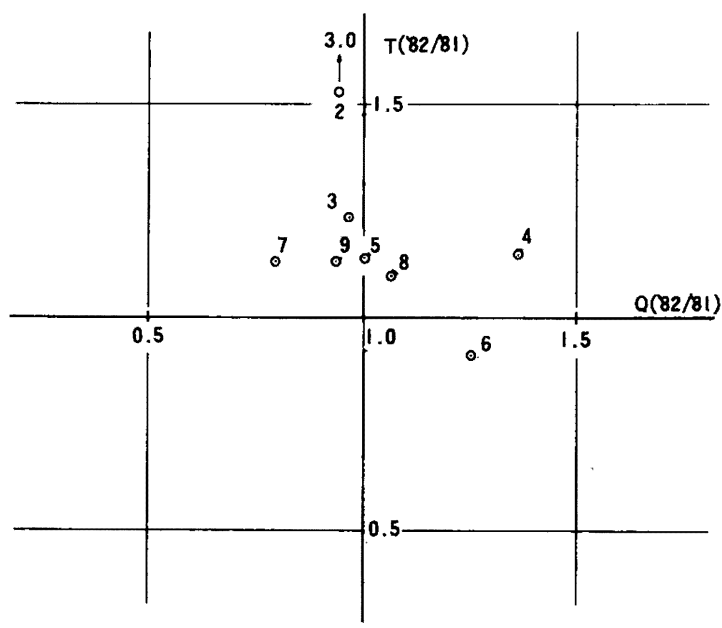

图-8 トリチウム $(\mathrm{T})$ と涌水量との関㐿.

Fig. 8 Relation between $\mathrm{T}$ composition and the ground water discharge.

3 水素・酸素同位体 $\left(\delta \mathrm{D} 、 \delta^{18} \mathrm{O}\right)$

坑内湧水の $\delta \mathrm{D}$ 値は-50 - $60 \%$ 、 $\delta{ }^{18} \mathrm{O}$ 值は一 $8.5 \sim-9.5 \%$ の値を示す。渓流水も同程度で顕著 な差は認められない。

図-9は $\delta \mathrm{D}$ と ${ }^{18} \mathrm{O}$ との関係をまとめたものであ るが、同図には1981年 $(O) 、 82$ 年 $(\triangle)$ 両年の值が示 してある。同図中の直線 A は Craig (1961)の示した 直線 $\left(\mathrm{d}: \delta \mathrm{D}-8 \delta^{18} \mathrm{O}=10.0\right)$ であるが、坑内湧水 は1981年、82年ともや、異った直線(破線、 $d: 14.9$ ) 上に位置している。図-9によると坑内湧水の $\delta \mathrm{D}$ 、 $\delta{ }^{18} \mathrm{O}$ 值は、1981年に対し82年は隇少傾向にあり、 渓流水は增大傾向にあること、No.1と No. 5とでは $\delta \mathrm{D}$ 值で5 6\%。、 $\delta{ }^{18} \mathrm{O}$ 值で0.6 0.8\%のの差のある こと、また、坑内湧水と渓流水とでは $\mathrm{d}$ 值に差が みられることなどが分る。このような要因として、 坑内湧水、渓流水の起源である降水の水素・酸素同 位体組成に対する温度、雨量、高度効果 (早稲田 ·

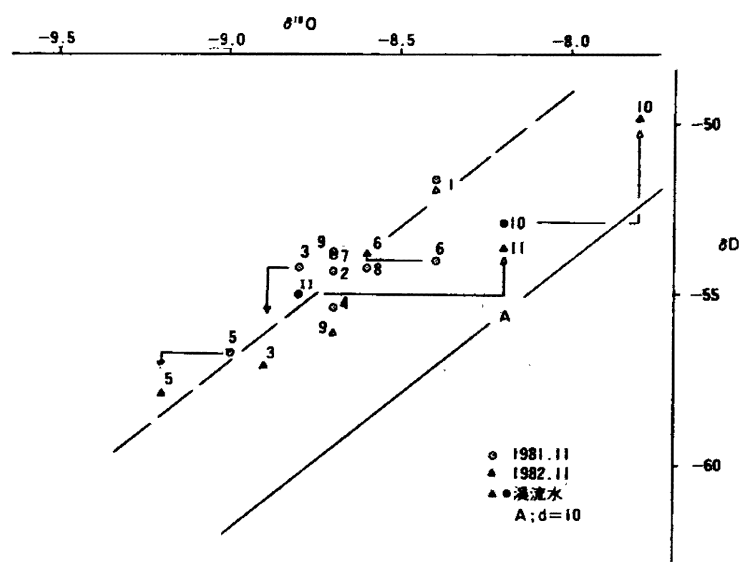

图-9 醋䅈 $\left({ }^{18} \mathrm{O}\right)$ と水秦 (D) 同位体組成.

Fig. 9 Oxygen-18 nd Deuterium isotopic composition of the ground water discharge.

中井、1983)などがあげられるが、今後、詳細な検 討が必要である。

\section{V まとめ}

調査個所における地下水の水質、同位体組成の特 徴を以下にまとめる。

1. 坑内湧水および溪流水の水質は $\mathrm{Ca}\left(\mathrm{HCO}_{3}\right)_{2}$ 型、 各組成分の濃度パターンは $\mathrm{Ca}^{2+}>\mathrm{Na}^{+}>\mathrm{Mg}^{2+} \gg$ $\mathrm{K}^{+} 、 \mathrm{HCO}_{3}{ }^{-}>\mathrm{SO}_{4}{ }^{2-}>\mathrm{Cl}^{-}$の関係を示し、全体と してほぶ同一の化学組成を有している。しかし、 No. 1、2湧水、および渓流水はや、その化学組成 を異にする。

2. 坑内湧水の総イオン濃度および電気伝導度はそ れぞれ1.5〜4.5epm、50〜200 $\mu_{\mathrm{s}} / \mathrm{cm}$ であるが、 各涌水によりや、異った値を示しその值は No. 1、 $2>$ No. 6 9>No. 3 5の関係にある。渓流水は坑 内涌水よりは小さく、それぞれ1.0epm、40 $\mathrm{s} / \mathrm{cm}$ 程度である。

3 . 坑内湧水の水温は全体として 12 C程度であるが、 No. 2はや、高い。溪流水は気温の影響を受けて いるものとみられるが、気温よりは比較的高い。 
4. 坑内涌水の $\mathrm{pH}$ は7.0〜7.4であるが、No. 2が相 対的にや、高い。渓流水は坑内湧水よりは小さく 6.9 程度である。

5. 坑内湧水の各組成分値間の相関係数は $\mathrm{Cl}^{-}$との 相関を除いて高い正相関を示し、坑内湧水は岩 石・水相互作用による化学組成変化が支配的で短 時間で浸透した地表水など比較的新しい地下水が 可成り混入していることを示唆しているものと考 えられる。

6 . 坑内湧水 ${ }^{222} \mathrm{Rn}$ 瀑度は $(1 \sim 25) \times 10^{-10} \mathrm{Ci} / \ell$ て 湧水量の変化に対し負相関を示し、比較的短時間 で浸透した地表水などの混入を示唆しているもの と考えられる。渓流水の ${ }^{222} \mathrm{Rn}$ 濃度は極めて小さ w。

7. $\mathrm{T}$ 漫度は坑内湧水、溪流水とも10 20 T. Uの 值を示し両者には顕著な差は認められない。坑内 湧水の $\mathrm{T}$ 浱度は湧水量に関係なく1981年と 82 年 の再年で10１5\%の増加を示し、降水の T 濃度 が增加しつつあった時期 (1953〜1963)の降水を起 源としていることを示唆しているものと考えられ る。

8. $\delta \mathrm{D} 、 \delta{ }^{18} \mathrm{O}$ 值は降水の温度、雨量、高度効果 などを示唆していると考えられるが、今後、詳細 な検討を必要としている。

以上、調査個所の湧水は降水の $\mathrm{T}$ 濃度が増加し
つつあった時期（1953～1963）の降水を起源とし比較 的短時間で浸透したと思われる地表水の混入が可成 り多いことを示唆されている。今後、引き続き実施 した水質、同位体調査結果をも含め詳細な検討によ り地下水の涵養源、地表水の混入特性などの地下水 モデルの解明を試み報告する予定である。

\section{的}

本研究に当っては、名古屋大学理学部 中井信之博士の 協力と有益な助言を得たことを記し深く感謝します。

\section{参考文献}

建設産業調査会 (1979) 「地下水ハンドブック」 p. 223.387. 框根 勇・田中 正・鵬田 純 (1980)：環境トリチウムで 追跡した関東ローム層中の土壤水の移動、地理学評論、 53-4、p. 225-237.

三木一美·吉沢 甫(1979) : トンネル湧水の発生形㦔と水 質変動について、土木学会論文報告集、第282号、p. 31.43. 早稲田 周・中井信之 (1983)：中部日本・東日本における 天然水の同位体組成、地球化学、17、p. 83-91.

Craig, H. (1961): Isotopic variation in meteoric waters. Science, 133, p. 1702.

Motozima, I. , Sismada, J. , Fujiwara, S. , Ohta, K. (1981): Proposal for the groundwater pressure measurement to investigate the groundwater movement in the bedrock, Proceedings of the international Symposium on weak rock. p. 491-496.

（受付：1984年 6 月14日、受理：1985年 4 月27日） 